Jože Kocjančič ${ }^{1}$

Štefan Bojnec ${ }^{2}$

UDK 674:<334.72:334.71>(497.4)

PRELIMINARY PAPER

PRETHODNO PRIOPĆENJE

\title{
DYNAMICS IN WOOD INDUSTRY IN SLOVENIA
}

\begin{abstract}
This paper investigates the dynamics of large wood industry enterprises on the dynamics of micro and small wood industry enterprises using firm-level survey data and time-series data. In addition, entry and exit of micro and small wood industry enterprises is explained by factors of demand, value-added, and profitability of capital. The empirical results show relatively modest impact of the dynamics of large enterprises on the dynamics of micro and small enterprises in the wood industry. The rate of value-added per employee and the rate of capital profitability are significantly associated with investments, particularly investments into new technological equipment. Easier access to financial means for micro and small enterprises at acceptable guarantees and reduction in costs of financing of capital are among possible measures to improve wood industry enterprise performance and entry into foreign markets as well as to efficiently reduce imports of wood raw materials and low value-added wood semi-products and to increase exports of higher value-added products and services.
\end{abstract}

JEL Classification: D22, L25, L69, C12, C81;

Keywords: Firm Dynamics, Competition, Wood Industry, Slovenia

\section{INTRODUCTION}

The aim of this research is to investigate the association between the changes in the number and importance of the large wood industry enterprises on the dynamics of entry and exit of small enterprises in the wood industry in Slovenia. Literature on dynamics of entry and exit of small enterprises have largely been developed for developed western market economies, while literature on Slovenia often focuses on the manufacturing sector as a whole.

This present paper focuses on the wood industry as one of the sectors in the Slovenian manufacturing sector. It contributes to literature on enterprise dynamics. In the first part, we present theoretical background as a starting point for empirical analysis of the dynamics of the wood industry enterprises in Slovenia. The research is based on economic theory and empirical analysis on performances of enterprises and determinants, which are determining entry and exit of enterprises (Antončič et al., 2002; Antončič, 2007; Hudson, 1986; Dunne et al., 1988; Davelaar, 1991; Machin and Reenen, 1993; Storey, 1994; Geroski and Walters, 1997; Audretsch et al., 2006; Smith et al., 2007; Kraus and Schwarz, 2007; Bojnec and Xavier, 2004, 2005, 2007). In the second, empirical part of this paper, we present empirical results of the research of the sample of micro and small Slovenian enterprises, which operate in the wood industry in Slovenia. The results might show in which degree and in which way the changes in the number and importance of large wood industry enterprises determine on the dynamics of entry and exit of new micro and small enterprises in this activity. We also

\footnotetext{
${ }^{1}$ University of Primorska, Faculty of Management Koper, Slovenia. Cankarjeva 5, 6000 Koper, e-mail: joze.kocjancic@siol.net.

${ }^{2}$ University of Primorska, Faculty of Management Koper, Slovenia. Cankarjeva 5, 6000 Koper, e-mail: stefan.bojnec@fm-kp.si.
} 
estimate regression analysis using time series statistical data on the associations between the dynamics of micro and small enterprises vis-à-vis the dynamics of large enterprises in the wood industry in Slovenia. Finally, we derive main conclusions and some proposals.

\section{THEORETICAL BACKGROUND AND MAIN EMPIRICAL FACTS}

Economic development is in a great extent determined by entrepreneurial orientation. Bierly and Muzyka (2000) on the sample of 500 dynamic western small enterprises show that even during economic recession dynamics of small enterprises experience positive job creation rates as well as growth in revenues. The empirical evidences for different countries show the importance of small and medium sized enterprises for creation of new jobs (Birch, 1979; Kirchhoff and Phillips, 1988; Davidsson et al., 1994; Storey, 1994; Picot and Dupuy, 1998).

\section{ECONOMIC IMPORTANCE OF DYNAMICS OF ENTERPRISES}

Economic efficiency of a country is determined by several factors. Dynamics of entry and exit of enterprises is a determinant without which the process of creative destruction would not be possible. New enterprises are inducing competitive pressures, fulfil market niches, and regenerate branch (Schumpeter, 1934). Entry of new enterprises, changes in size structures and exit of enterprises have a crucial impact on a country's economic growth. Several new emerging enterprises, which are entering in a market, provide opportunities for easier and faster adjustments in the economy on technological changes and utilisation of new business opportunities.

The positive rate of dynamics of entry of new enterprises creates greater competition, which encourages the existing enterprises to struggle for market shares, induces needs for restructuring and more efficient operation. On the other hand, the increased enterprise entry competition can cause exit of less efficient enterprises from the market, which improves resource allocative efficiency from less to more productive enterprises and activities (Foster et al., 1998, Scarpetta et al., 2002, Brown et al., 2004). The dynamics of entry and exit of enterprises have the crucial role for competitive market economy, particularly during the periods of structural reforms, when economic growth, which is based on existing industries and markets, is in a stagnating stage. In such periods the economic growth depends particularly on ability to gains new markets and activities. These are areas, which largely depend on more efficient new enterprises and entrepreneurs (Davelaar, 1991). The institutional environment, which represents an enabling environment for business performance of enterprises, dynamics of entry and growth of new enterprises and enterprise survival, often indicates a crucial association with general economic performance indicators by countries. Due to these reasons, the demography of enterprises is one of most important indicators, which indicates the rate of efficiency of countries (Brandt, 2004).

\section{DETERMINANTS OF DYNAMICS OF ENTERPRISES}

Dynamics of entry and exit of enterprises is determinant by several factors, which are associated to changes in macro-economic environment of an enterprise (Hudson 1986; Robson 1996). Market demand and supply, market growth, employment rate, and technological changes are only some factors, which are determining the rate of profitability and associated dynamics of entry and exit of enterprises (Geroski and Machin, 1993; Machin 
and Reenen, 1993; Geroski and Walters, 1997). Enterprise size, enterprise ownership structure, competitive pressures, market orientation and branch characteristics are also important factors, which determine dynamics of enterprises. Dynamics of micro and small enterprises is in a great extent determined by factors of enabling enterprise environment and factors of the role of entrepreneur. From an economic point of view, dynamics of entry of new enterprises and dynamics of exit of inefficient enterprises crucially influence on economic growth of an economy. From broader social point of view, dynamics of enterprises has important role for capital allocation and job creation, which is important for economic growth and social cohesion.

Slovenia has experienced relatively a high percentage of exits among the new enterprises, which suggest low efficiency and survival rate among newly established enterprises. The high percentage of exits among newly established enterprises imply losses of invested means. The resources, which were invested in a certain activity, were not profitable and might be better to reallocate them in another more productive investment opportunity. In 2004, the exit rate among newly established enterprises in Slovenia was around 37\% implying that ten enterprises out of 27 newly established enterprises survived. The highest exit rate among newly established enterprises in the EU was only in France (Minniti et al., 2006). In 2005 the exit rate among newly established enterprises declined and thus the survival rates increased.

In 2005 in Slovenia were set up 8,400 new enterprises, which represented almost 45\% more than in 2000. During the same period the increase in the number of employees in the newly established enterprises was less substantial, as it increased by $16 \%$. The newly established enterprises are mostly micro and small enterprises. In 2000, in the newly established enterprises on average were employed 1.66 persons per enterprise, while in 2005 it was 1.34 persons per enterprise, which shows the decline in the average employment size of the newly established enterprises (SORS, 2008).

\section{WOOD INDUSTRY IN SLOVENIA}

The wood industry is classified among manufacturing activities. It includes production of sawn wood, plywood and plates, impregnated wood, production of furniture, packaging, building furniture and other products from wood. The wood industry in Slovenia is ranked among the first thirds of the most important economic activities within the manufacturing activities. From point of view of contributions to employment, revenues and gross value added it is almost twice as important as it is in the other EU countries. On the other hand, productivity in the Slovenian wood industry is almost twice less than on the average of the branch in the EU countries (Kožar, 2006). The main problems, which the Slovenian wood industry is facing, are its relatively low international competitiveness, low labour productivity, and heavily indebtedness. For the Slovenian wood industry is typical high concentration of enterprises, which produce semi products and products with low value added, which is an additional factor, which due to relatively high production cots reduces competitive position of the wood industry enterprises.

The Slovenian wood industry is important in employment and in generation of value added in the economy. In 2006, in the Slovenian wood industry were operating 2,586 enterprises, which employed 23,757 persons, which represented $4.09 \%$ of employment in the Slovenian manufacturing activities. In the same year, wood industry contributed $4.86 \%$ of revenues and $1.77 \%$ of net pure profit of the Slovenian manufacturing activities. Net revenue from sales in the Slovenian wood industry amounted to 1.09 billion euro, and $50.1 \%$ of all revenues were realized at the foreign markets. 
During the period 2000-2006, the dynamics of entry of new enterprises in the Slovenian wood industry shows relatively balanced dynamics of the share of newly established enterprises by the individual years, which on average is between $2.93 \%$ in 2006 and $4.4 \%$ in 2004. The average survival rate of the newly established enterprises, which survived the first year of operation, is almost $92 \%$ and is reduced on average to $62 \%$ of the newly established firms, which survived the first five years of operation (SORS, 2008).

\section{METHODOLOGY AND DATA}

The research aims to investigate the causalities between the dynamics of the number of the large enterprises and entry of new and exit of micro and small enterprises in the wood industry in Slovenia. We aim to investigate determinants of changes in the number and size structure of the large enterprises in the wood industry and the dynamics of entries and exits of micro and small enterprises. On the basis of comparisons of the obtained empirical results of the research with a similar research in literature we derive implications for entrepreneurial decisions at the enterprise level and for needs of economic policy.

The data collection for the selected sample of micro and small enterprises is conducted by using the written questionnaire, which was sent by post-mail to the randomly selected addresses of the population of the micro and small enterprises in the wood industry. The micro and small enterprises were selected on the basis of the registry of enterprises. The micro, small and large enterprises are defined according to the Slovenian legislation where at least two criteria should be fulfilled. A micro enterprise is defined as: average number of employees in a business year is equal or less than 9 employees, net revenues is equal or less than 2 million euro, and active value in balance sheet of an enterprise is equal or less than 2 million euro. A small enterprise is defined as: average number of employees in a business year is equal or less than 50 employees, net revenues is equal or less than 7.3 million euro, and active value in balance sheet of an enterprise is equal or less than 3.65 million euro. A large enterprise is defined as: average number of employees in a business year is more than 250 employees, net revenues is more than 29.200 million euro, and active value in balance sheet of an enterprise is more than 14.6 million euro.

The surveys in the Slovenian micro and small wood industry enterprises with the written questionnaire were conducted between the third quarter of 2008 and the beginning of 2009. The written questionnaire was accompanied by a cover letter and pre-paid return envelope. The answers on the questions were in the form by using the Likert's scale (Easterby-Smith et al., 2005). There were five possible responses on the basis of the intensity of agreement or disagreement with the possible response on the question by the Likert's scale, where 1 means not important at all, 2 is not important, 3 is neutral, 4 important, and 5 very important.

In 2007 the population of the Slovenian micro and small enterprises in the wood industry comprises of 2,342 enterprises, and there were 18 large enterprises (Table 1). In the randomly selected survey sample were included almost $21 \%$ of the population of the micro and small enterprises, which were engaged in the wood industry. This means around 700 micro and small enterprises. The completed and returned were 168 questionnaires. 
Table 1:

Population of enterprises in the wood industry in Slovenia, 2007

\begin{tabular}{lrrrr}
\hline & \multicolumn{2}{c}{ Number of } & \multirow{2}{*}{ Number of employees } \\
& \multicolumn{2}{c}{ enterprises } & & DN36 \\
Standard Classification of Activities & DD20 & DN36 & DD20 & DN36 \\
Micro enterprise (0 - 9 employees) & 1,520 & 1,568 & 3,030 & 3,139 \\
Small enterprise (10 - 49 employees) & 119 & 117 & 2,326 & 2,524 \\
Total number of micro and small enterprises & 1,639 & 1,685 & 5,356 & 5,663 \\
Large enterprises (more than 250 employees) & 6 & 12 & 3,385 & 5,212 \\
Total number of enterprises in population & 1,645 & 1,697 & 8,741 & 10,875 \\
\hline
\end{tabular}

Note: DD20 - Manufacture of wood and wood products. DN36 - Manufacture of furniture, manufacturing not elsewhere classified.

Source: SORS 2009

Our main thesis is that the entries and exits of micro and small enterprises, and economic efficiency in the wood industry in Slovenia, are directly associated with the dynamics in the number and importance of the large enterprises in this industry. In addition to the unique enterprise survey data, we employ also statistical time series data for the years 1989 to 2007. As the methods of the empirical analyses we employ descriptive statistics and t-test analysis of the survey data, and time series regression analysis (e.g. Forster et al. 2006, Mele 2010).

\section{DYNAMICS OF LARGE ENTERPRISES AS DETERMINANT OF DYNAMICS OF MICRO AND SMALL ENTERPRISES IN THE WOOD INDUSTRY}

The basic theoretical and empirical knowledge on enterprise performance, entrepreneurship, and market dynamics of entry and exit of enterprises are based on studies for western market economies, for transition and emerging market economies (Antončič et al., 2002; Hudson, 1986; Dunne et al., 1988; Davelaar, 1991; Machin and Reenen, 1993; Storey, 1994; Geroski and Walters, 1997; Audretsch et al., 2006; Smith et al., 2007; Kraus and Schwarz, 2007; Bojnec and Xavier, 2004, 2005, 2007). We aim to investigate the changes in the number and importance of large wood industry enterprises on the dynamics of entry of newly established small enterprises as a response to the emerging gaps in supply of products and services, which have occurred with the exit of large enterprises or with the changing their size.

\section{CHANGES IN LARGE ENTERPRISES ON DYNAMICS OF MICRO AND SMALL ENTERPRISES}

Literature argues that dynamics of enterprise exit increases with the increases in financial instability, which is consistent with hypothesis on enterprise life cycle (Vernon, 1996). Both dynamics of entry and dynamics of exit of enterprises vary with respect to rate of nominal and real financial stability. Economic cycle, which is defined by macro-economic variables such as developments in demands, rate of unemployment and growth in supply, causes on the rate of profitability (Geroski and Machin, 1993; Machin and Van-Reenen, 1993; Geroski et al., 1997), which are determining the dynamics of entries and exits of enterprises.

The analysis of the opinions of the respondents in the Slovenian wood industry enterprises on the question how dynamics in the reduction of the number of large enterprises determines the dynamics of entry of micro and small enterprises, shows that the dynamics in the reduction in the number of large enterprises on the dynamics of entry of micro and small 
enterprises in the wood industry is less clear or relatively modest (Table 2 ). The average value of the responses is 3.09 (Likert scale from 1 to 5) with standard deviation 1.142 of estimates.

\section{Table 2:}

Impact of reduction in the number of large enterprises on the dynamics of micro and small enterprises in the wood industry in Slovenia, 2009

\begin{tabular}{|c|c|c|c|c|c|}
\hline \multirow{4}{*}{$\begin{array}{l}\text { Impact of reduction in the number of } \\
\text { large enterprises on: } \\
\text { - dynamics of entry of micro and } \\
\text { small enterprises } \\
\text { - dynamics of exit of micro and small } \\
\text { enterprises }\end{array}$} & \multicolumn{5}{|c|}{ Interval of estimate of mean value } \\
\hline & $\mathrm{N}$ & $\begin{array}{c}\text { Mean } \\
\text { value }\end{array}$ & Modus & Median & $\begin{array}{l}\text { Standard } \\
\text { deviation }\end{array}$ \\
\hline & 168 & 3.09 & 3 & 3.00 & 1.142 \\
\hline & 165 & 3.00 & 3 & 2.00 & 1.161 \\
\hline
\end{tabular}

The analysis of the opinions by the respondents on the question how reduction in the number of large enterprises in wood industry in Slovenia determines the dynamics of exit of micro and small enterprises in the wood industry according to the mean value of the opinions by the respondents show similar or even smaller importance than on the dynamics of entry of newly established micro and small enterprises in the wood industry. For the former the mean value of responses is equal 3 (neutral) with standard deviation of estimate 1.161. On the basis of previous analysis and our results we can conclude that the reduction in the number of large enterprises in the wood industry determines the dynamics of entry and exit of micro and small enterprises in a smaller degree, while crucial determinants of dynamics seem to be factors of demands for enterprise products and services and of enterprise enabling macro-economic environment such as rate of unemployment and degree of financial stability.

\section{IMPACT OF OUTPUT DEMAND ON DYNAMICS OF ENTRY OF MICRO AND SMALL ENTERPRISES}

As a consequence of the reduction in the number and size structure of large enterprises, there is a reduction in a local supply of products and services, which is substituted by more efficient domestic enterprises and foreign import competition (Bojnec and Xavier, 2007). The empirical results on the question in which degree new demand, which is determined by the exit of large enterprise from the output market, determines the entry of a greater number of newly established micro and small enterprises, which are substituting output supply in the wood industry, shows modest positive association on the dynamics of entry of newly established micro and small enterprises in the wood industry. The average value of opinions by the respondents is 3.43 (Likert scale from 1 to 5), which means neutral or relatively modest impact of newly emerged output demands on the dynamics of entry of micro and small enterprises in the wood industry (Table 3). 
Table 3:

Impact of output demand on dynamics of entry of micro and small enterprises in the wood industry in Slovenia, 2009

\begin{tabular}{|c|c|c|c|c|c|}
\hline & \multicolumn{5}{|c|}{ Interval of estimate of mean value } \\
\hline & $\mathrm{N}$ & $\begin{array}{l}\text { Mean } \\
\text { value }\end{array}$ & Modus & Median & $\begin{array}{r}\text { Standard } \\
\text { deviation }\end{array}$ \\
\hline $\begin{array}{l}\text { Impact of output demand on } \\
\text { dynamics of entry of small } \\
\text { enterprises }\end{array}$ & 165 & 3.43 & 4 & 4.00 & 1.000 \\
\hline
\end{tabular}

The previous research on the dynamics of micro and small enterprises in the wood industry has shown that on the decision for the start up and entry of enterprises are determined by factors of environment of micro and small enterprises and factors of the role of entrepreneurs (Kocjančič and Bojnec, 2008). Among the factors of the enterprise enabling environment are significant for example the share of market sales, ability of financing of current operation and delay payments with payments disorder. Therefore, we analyse and compare the opinions of the respondents on the set question, which shows that the increased output demand, which resulted as the consequence of the exit of large enterprises from the market, has modest positive impact on the dynamics of entry of micro and small enterprises in the wood industry.

\section{IMPACT OF COMPETITION FROM MICRO AND SMALL ENTERPRISES ON INDICATORS OF EFFICIENCY}

Labour intensive branches such as the wood industry show a greater dynamics of entry of micro and small enterprises than exits. As a result, this leads to a higher concentration in the branch, which might in a negative way determine enterprise business performance and leads to greater rates of exits of enterprises in a certain branch (Bojnec and Xavier, 2004, 2005, 2007).

We use five questions to investigate the impact of the greater number of micro and small enterprises in the Slovenian wood industry on the rate of competition and indicators of efficiency in the wood industry. In these questions are captured impacts of increased number of new micro and small enterprises on the rate of value-added, employment rate, rate of valueadded per employee, rate of competition, and rate of economic efficiency of growing survived enterprises. This analysis of the opinions by the respondents on these questions gives an overview on the extent in which the increased number of new micro and small enterprises in the wood industry determines enterprise performance by individual selected indicators of enterprise efficiency. Table 4 shows that on the basis of the opinions by the respondents on the asked question we can conclude that the increased number of micro and small enterprises has neutral up to important impact on the investigated indicators of enterprise efficiency in the wood industry in Slovenia. The greatest is the impact of the increased number of micro and small enterprises on the economic efficiency of the growing survived enterprises. 
Table 4:

Impact of competition from micro and small enterprises on indicators of enterprise efficiency in the wood industry in Slovenia

\begin{tabular}{|c|c|c|c|c|c|}
\hline $\begin{array}{l}\text { Impact of a greater number of small } \\
\text { enterprises on: }\end{array}$ & $\mathrm{N}$ & $\begin{array}{l}\text { Mean } \\
\text { value }\end{array}$ & Modus & Median & $\begin{array}{r}\text { Standard } \\
\text { deviation }\end{array}$ \\
\hline $\begin{array}{l}\text { - rate of value-added in wood } \\
\text { industry }\end{array}$ & 156 & 3.06 & 3 & 3.00 & 1.011 \\
\hline - employment rate & 156 & 3.29 & 4 & 3.50 & 0.990 \\
\hline $\begin{array}{l}\text { - rate of value-added per } \\
\text { employee }\end{array}$ & 156 & 3.38 & 4 & 3.50 & 1.062 \\
\hline $\begin{array}{l}\text { - competition and rate of } \\
\text { profitability of capital }\end{array}$ & 168 & 3.23 & 4 & 3.00 & 0.966 \\
\hline $\begin{array}{l}\text { - economic efficiency of growing } \\
\text { survived enterprises }\end{array}$ & 168 & 3.41 & 4 & 4.00 & 1.017 \\
\hline
\end{tabular}
very important. $\mathrm{N}=$ number of observations.

New micro and small enterprises are often oriented into innovative activities and have important role in job creation. Market dynamics by entry of new, more efficient enterprises and exit of less productive and less efficient enterprises have important role in reallocation of resources from less to more productive ones (Scarpetta et al., 2002, Foster et al., 1998). We can conclude that the increased number of the newly established micro and small enterprises determines all aspects and indicators of wood industry enterprise performance and efficiency. Newly established and in innovation oriented micro and small enterprises are creating competitive pressures, which causes different resource allocation and income distribution from less to more productive and efficient enterprises.

\section{IMPACT OF INDICATORS OF EFFICIENCY ON INVESTMENT ACTIVITIES}

The rate of value-added per employee and the rate of capital profitability are factors that have impacts on investments and particularly on investments in advanced technological equipment. In cases that the values of indicators are lower than alternative opportunity revenues, then we can expect that capital starts to move out of a branch. We ask the respondents two questions on the impact of indicators of efficiency on investments in the Slovenian wood industry: first, what is the impact of the rate of value-added per employee in the industry on the investments in new technological equipment, and second, what is the impact of rate of capital profitability on investments. The analysis of opinions by the respondents on the asked questions gives the evidence in what extent the individual factors of efficiency are determining investment activities in the wood industry. Table 5 presents the opinions of the respondents on the asked questions. Both the rate of capital profitability and the rate of value-added per employee determine importantly the decisions on the investments in the wood industry in Slovenia. 
Table 5:

Impact of indicators of micro and small enterprise efficiency on investments in the wood industry in Slovenia

\begin{tabular}{|c|c|c|c|c|c|}
\hline \multirow[b]{2}{*}{ Determinants: } & \multicolumn{5}{|c|}{ Interval of estimate of mean value } \\
\hline & $\mathrm{N}$ & $\begin{array}{l}\text { Mean } \\
\text { value }\end{array}$ & Modus & Median & $\begin{array}{l}\text { Standard } \\
\text { deviation }\end{array}$ \\
\hline $\begin{array}{l}\text { Impact of value-added per } \\
\text { employee on investments in } \\
\text { technological equipment }\end{array}$ & 162 & 4.00 & 4 & 4.00 & 0.946 \\
\hline $\begin{array}{l}\text { Impact of capital profitability on } \\
\text { investments }\end{array}$ & 162 & 4.30 & 4 & 4.00 & 0.787 \\
\hline
\end{tabular}

Notes of opinions: 1 - not important at all; 2 - not important; 3 - neutral; 4 - important; 5 very important. $\mathrm{N}=$ number of observations.

Vernon (1966) argues that the life cycle of demands and foreign direct investments are reflected in international migration of labour intensive branches. We can conclude that the rate of value-added per employee and the rate of capital profitability determine importantly on investments in advanced technological equipment as well as on total investments. In other case we could expect flows of capital from the branch or movement of production into less developed or developing countries with cheaper costs of labour.

\section{RESULTS OF TESTING RESEARCH HYPOTHESES AND REGRESSION ANALYSIS}

\section{Testing research hypotheses}

In the Slovenian wood industry is relatively high concentration of enterprises: $1 \%$ of enterprises contribute $25 \%$ of total revenues, while $3 \%$ of the largest enterprises contribute more than 50\% of total revenues (SKEP GZS 2007). On the basis of these empirical facts we set the first research hypothesis:

Hypothesis 1 (H1): The reduction in the number and size structure of the large enterprises in the wood industry in a greater degree determines on the dynamics of entry of new micro and small enterprises than on the dynamics of exit of the existing micro and small enterprises.

To test H1, we employ t-test with the following two variables: NLE_ESE - impact of number of large enterprises on dynamics of entry of micro and small enterprises, and SLE_ESE - impact of average size of large enterprises on dynamics of entry of micro and small enterprises.

Table 6:

$t$-distribution (number of large enterprises, average size of large enterprises)

$t$-distribution of variables: NLE_ESE - number of large enterprises / entry of micro and small enterprises, SLE_ESE - average size of large enterprises / entry of micro and small enterprises

$$
\text { test value }=3
$$

\begin{tabular}{lcrrrrr} 
& & & & & \multicolumn{2}{c}{$95 \%$ interval of } \\
& t-test & df & p-value & \multicolumn{1}{c}{$\begin{array}{c}\text { Average } \\
\text { deviation }\end{array}$} & Minimum & Maximum \\
NLE_ESE & 1.014 & 167 & 0.312 & 0.089 & -0.08 & 0.26 \\
SLE_ESE & -1.404 & 167 & 0.162 & -0.125 & -0.30 & -0.05 \\
\hline
\end{tabular}


On the basis of the sample of micro and small enterprises in the wood industry, we cannot conclude that the smaller number of large enterprises and smaller average size of large enterprises (reduction in the number of employees in large enterprises) are positively associated with entry of new micro and small enterprises. Because the significance level is greater than $\alpha=0.05$ (Table 6), we cannot conclude that the reduction in the number and size structure of large enterprises in the wood industry determines greater dynamics of entry of new micro and small enterprises.

Labour intensive branches due to low entry capital requirements show greater share of entries of new enterprises than exits of the existing enterprises, because labour is relatively cheaper factor for new enterprises (Bojnec and Xavier, 2007). Fastest dynamics of entry of new micro and small enterprises is reflected in increasing branch competitive supply, which increases branch market competition. Following from this, we define the second hypothesis:

Hypothesis 2 (H2): Greater dynamics of entry of new micro and small enterprises than exit of existing of micro and small enterprises has the implication on an additional reduction in the values of indicators of value-added per employee and consequently with this has a negative impact on business performance of the wood industry as a whole.

To test H2, we employ t-test with the following three variables: ESE_VAE - impact of entry of new micro and small enterprises on value-added per employee, ESE_RCP - impact of entry of new micro and small enterprises on rate of capital profitability, and ESE_EGSE impact of entry of new micro and small enterprises on economic efficiency of growing survived enterprises.

\section{Table 7:}

$t$-distribution (value-added per employee, rate of capital profitability, and economic efficiency of growing survived enterprises)

$t$-distribution of variables: ESE_VAE - entry of micro and small enterprises / value-added per employee, ESE_RCP - entry of micro and small enterprises / rate of capital profitability, ESE_EGSE - entry of micro and small enterprises / economic efficiency of survived growing enterprises test value $=3$

\begin{tabular}{lrrrrrr} 
& & & \multicolumn{2}{c}{ test value $=3$} & \multicolumn{2}{c}{$95 \%$ interval of } \\
& \multicolumn{1}{c}{} & & & \multicolumn{2}{c}{ Average } & \multicolumn{2}{c}{$\begin{array}{c}\text { confidence } \\
\text { d-test }\end{array}$} & df & p-value & deviation & Minimum & Maximum \\
ESE_VAE & 4.522 & 155 & 0.000 & 0.385 & 0.22 & 0.55 \\
ESE_RCP & 3.114 & 167 & 0.002 & 0.232 & 0.08 & 0.38 \\
ESE_EGSE & 5.235 & 167 & 0.000 & 0.411 & 0.26 & 0.57 \\
\hline
\end{tabular}

On the basis of the survey data we can conclude that the average score for the answers, which is greater than 3 (neutral) by using the Likert's scale from 1 to 5 , is consistent with the set hypothesis $\mathrm{H}_{0}: \mu_{0}>3$ and inconsistent with the alternative hypothesis $\mathrm{H}_{\mathrm{A}}: \mu_{1} \leq 3$. Due to this on the basis of the empirical results in Table 7, we can conclude that the increased dynamics of entry of new micro and small enterprises has the implications for the reduction in the value of indicators for the value-added per employee. The entry of new micro and small enterprises contributes to the increased competition in the wood industry. With the increased competition and dynamics in the market selection process this causes the economic efficiency of the growing survived enterprises in a positive direction. 


\section{REGRESSION ANALYSIS}

With the regression analysis we analyse two hypotheses. We first test hypothesis 3 (H3) on the dependence of the number of micro and small enterprises in the wood industry from the number of large enterprises and the number of employees in the large enterprises.

In the regression analysis we use data on the average number of large enterprises (NLE), the average number of micro and small enterprises (NSE), the average number of entries of micro and small enterprises (ESE), and the average number of employees in large enterprises (ELE). We use time-series data by the individual years in the period 1989-2007 in the wood industry for the groups DD20 and DN36. The source of data is the SORS 2009 (SI-Stat). We use linear regressions, which are estimated by the ordinary least square (OLS) method. We estimate the following NSE linear regression function: NSE $=\mathrm{a}+\mathrm{b} 1 * \mathrm{NLE}+\mathrm{b}_{2} * \mathrm{ELE}$. The estimated regression function is: $\mathrm{NSE}=5257.385+134.672 * \mathrm{NLE}-0.477 * \mathrm{ELE}$ [regression (1) in Table 8]. The regression results indicate that the number of micro and small enterprises in the wood industry on average increases by 135 if the number of large enterprises in the wood industry increases by 1 . This suggests positive complementary effects between the number of micro and small enterprises and the number of large enterprises in the wood industry. The positive association implies that the number of micro and small enterprises and the number of large enterprises have increased during the wood industry and overall economic expansion during the analysed period.

Table 8:

Estimated regression models, 1989-2007

\begin{tabular}{|l|l|l|l|l|lr|}
\hline $\begin{array}{l}\text { Dependent } \\
\text { variable }\end{array}$ & Constant & NLE & ELE & Adjusted R $^{2}$ & F-test & \\
\hline$(1)$ NSE & 5257.385 & 134.672 & -0.477 & 0.39 & $\begin{array}{l}6.718 \\
0.008)\end{array}$ & (Sig. \\
\hline & $(10.556)^{* * *}$ & $(2.187)^{* *}$ & $(-2.733)^{* * *}$ & & & (Sig. \\
\hline$(2)$ ESE & 154.892 & 7.207 & -0.016 & 0.13 & 1.142 \\
& & & & & $0.345)$ & \\
\hline & $(2.819)^{* * *}$ & $(1.057)$ & $(-0.817)$ & & & \\
\hline
\end{tabular}

***/**: statistically significant, respectively at the $1 \%$ and $5 \%$ levels.

Note: NSE - number of micro and small enterprises, ESE - number of entries of micro and small enterprises, NLE - number of large enterprises, and ELE - number of employees in large enterprises.

In addition, the regression results confirm $\mathrm{H} 3$ that the number of micro and small enterprises in the Slovenian wood industry on average increases by 0.48 , when the number of employees in large enterprises declined by 1 . This implies that the number of micro and small enterprises in the wood industry increases with the declines in the number of employees in the large wood industry enterprises. However, it is likely that during the economic growth there is an increase in demands for labour both in large and small enterprises. Due to this, a certain number of employees in large enterprises in the wood industry are likely to recognize entrepreneurial opportunities, which is arising from increases in output market demands and decide to shift from employment in large enterprise into self-employment in micro and small enterprise. This can cause a short-term labour mismatch in large enterprises.

Second, we test hypothesis 4 (H4) on the dependence of the number of entries of micro and small enterprises in the wood industry from the number of large enterprises and the number of employees in the large enterprises in the same branch.

We estimate the following ESE linear regression function: $E S E=a+b_{1} * N L E+b_{2} * E L E$. The estimated regression function is: $\mathrm{ESE}=154.892+7.207 * \mathrm{NLE}-0.016^{*} \mathrm{ELE}$ [regression (2) in Table 8]. On the basis of our regression results we cannot reject the $\mathrm{H} 4$ that the dynamics in 
the number of large enterprises and the dynamics in the size structure of large enterprises are determining the dynamics of the entry of new micro and small enterprises in the wood industry. We find a positive linear association between the number of large enterprises and the number of micro and small enterprises in the Slovenian wood industry. As expected, the number of micro and small enterprises in wood industry increases with the decline in the number of employees in large enterprises in the wood industry.

We can conclude that the increases in output demands, which are associated with positive economic developments, are also a positively associated with the increases of the number of large, micro and small enterprises in the wood industry. On the other hand during the periods of positive economic developments the increase in the number of micro and small enterprises in the wood industry is also due to the decline in the number of employees in the large enterprises.

\section{CONCLUSION}

The wood industry in Slovenia is faced by transformation and structural changes, which are determined by the increased output market competition from suppliers at the enlarged EU markets. On the other hand, there are opportunities for demands and sales of products and services at local, regional, EU and global markets. This can be important for employment and incomes. The rate of value-added per employee and the rate of profitability of capital show relatively high association with investments and particularly investments into new technological equipment. The greater entry of newly established micro and small enterprises with the greater output market competition encourages the greater innovation focus and increased degree of productivity of successful survived growing enterprises, which are forced by market pressures mechanisms and market selection processes to create new products and services with a higher value-added per a unit of product. Consequently, this increases also the degree of value-added per employee. This is also a way that contributes to the improved performances and efficiencies of the wood industry enterprises in catching up to value-added per employee, which on average is achieved by the manufacturing activities and the Slovenian economy as a whole.

Unlike to our theoretical expectation and hypotheses that the reduction in the number and size structure of large enterprises in the wood industry in a greater extent causes the dynamics of entry of new micro and small enterprises, the empirical results show small to less important impact of the reduction in the number and size structure of large enterprises in the wood industry on the dynamics of micro and small enterprises in the wood industry. Therefore, as an issue for future research are determinants of efficiency in the wood industry enterprises in Slovenia. The Slovenian wood industry enterprises lack financial means, which are needed for restructuring and growth, and for entry into foreign more competitive markets. In the Slovenian wood industry exports are still important wood raw materials and semi-processed products with relatively low value-added per product. This has been a survival strategy in the past, but it is a challenging issue for future growth and survival as an issue for future research.

\section{REFERENCES}

Antončič, B., Hisrich, R.D., Petrin, T. and Vahčič, A., (2002), Podjetništvo, (Ljubljana: GV založba).

Antoncic, B., (2007), "Intrapreneurship: a comparative structural equation modeling study", Industrial Management \& Data Systems 107 (3): 309-325.

Audretsch, D. B., Keilbach, M. C. and Lehmann, E. E., (2006), "Entrepreneurship and economic growth", (Oxford: Oxford University Press). 
Bierly, S. and Muzyka, F. D., (2000), Mastering entrepreneurship: complete MBA companion in entrepreneurship, (London: Prentice Hall, Financial Times Business Ltd.).

Birch, D. L., (1979), The job creation process, (Unpublished report: MIT Program on Neighbourhood and Regional Change).

Bojnec, Š. and Xavier, A., (2004), "Entry and exit in transition economies: the case of the Slovenian manufacturing sector", Post-Communist Economies, 16 (2): 191-214.

Bojnec, Š . and Xavier, A., (2005), "Firm and labour dynamics in Slovenian manufacturing", Društvena istraživanja, 14 (6): 1103-1127.

Bojnec, $\breve{S}$. and Xavier, A., (2007), "Determinants of firm exit in the Slovenian manufacturing”, Industrial Management \& Data Systems, 107 (5): 715-727.

Brandt, N., (2004), Business Dynamics in Europe, (Paris: OECD).

Brown, G., Hewitt, P., Eichel, H., Clement, W., Mer, F. and Dutreil. R., (2004), Towards an enterprising Europe, (A paper by the French, German and UK Governments).

Davidsson, P., Lindmark, L. and Olofssen, C., (1994), "New firm formation and regional development", Sweden Regional Studies Association 28 (4): 395-410.

Davelaar, E. J., (1991), Regional Economic Analysis of Innovation and Incubation, (Aldershot: Avebury).

Dunne, T., Roberts, M. J. and Samuelson, L., (1988), "Patterns of Firm Entry and Exit in US Manufacturing Industries", Rand Journal of Economics 19 (2): 495-515.

Easterby-Smith, M., Thorpe, R. and Lowe, A., (2005), Raziskovanje v management, (Koper: Faculty of Management, Koper).

Foster, J.J., Barkus, E. and Yavorsky, C., (2006), Understanding and using advanced statistics, (London: SAGE Publications Ltd).

Foster, L., Haltiwanger, J. and Krizan, C. J., (1998), Aggregate productivity growth: Lessons from microeconomic evidence, (Cambridge: National Bureau of Economic Research).

Geroski, P., and Machin, S., (1993), "Innovation, profitability and growth over the business cycle", Empirica, 20 (1): 35-50.

Geroski, P., and Walters, C., (1997) "Corporate growth and profitability", Journal of Industrial Economics, 45 (2): 171-189.

Hudson, J., (1986), "Company liquidations in England and Wales", Applied Economics, 18 (2): 219-235.

Kirchhoff, B. and Phillips, B. D., (1988), "The effect of firm formation and growth of on job creation", Journal of Business Venturing, 3 (4): 261-272.

Kraus, S. and Schwarz, E., (2007), "The role of pre-start-up planning in new small business", International Journal of Management and Enterprise Development, 4 (1): 1-17.

Kocjančič, J. and Bojnec, Š., (2008), "Factors of small enterprise dynamics in the wood industry", International Journal of Management and Enterprise Development, 5 (5): 529540.

Kožar, V., (2006), "Kako uresničiti vizijo in doseči razvojni preboj”, E-informacije, glasilo GZS, Združenje lesarstva, 2. Http://www.gzs.si/pripone/13486/ oei27545d13486a27 6a9550a .doc (December 2008).

Machin, S. and Reenen, V. J., (1993), "Profit margins and this business cycle: evidence from UK manufacturing firms", Journal of Industrial Economics, 41 (1): 29-50.

Mele, M., (2010), "A "time series" approach on the Chinese exchange rate regime", Ekonomska istraživanja, 23 (3): 1-11.

Minniti, M., Bygrave, W. D. and Autio, E., (2006), Global entrepreneurship monitor 2005 executive export, (London: London Business School).

Picot, G. and Dupuy, R., (1998), "Job creation by company size class: The magnitude, concentration and persistence of job gains and losses in Canada", Small Business Economics Journal, 10 (2): 117-139. 
Robson, M. T., (1996), "Macroeconomic factors in the birth and death of UK firms: evidence from quarterly VAT registration", The Manchester School 64 (2): 170-188.

Scarpetta, S., Hemmings, P., Tressel, T. and Woo, J., (2002), The role of policy and institutions for productivity and firm dynamics: evidence from micro and industry data, (Paris: OECD).

Schumpeter, J., (1934), The theory of economic development, (Cambridge: Harvard University Press).

SKEP GZS, (2007) Poslovanje gospodarskih družb v letu 2006. Pregled in analiza po dejavnostih, (Ljubljana: Gospodarska zbornica Slovenije).

Smith, W. L., Schallenkamp, K. and Eichholz, D.E., (2007), "Entrepreneurial skills assessment: an exploratory study", International Journal of Management and Enterprise Development, 4 (2): 179-201.

SORS, (2008), Poslovni subjekti, novo nastala podjetja brez predhodnika, (SI-Stat podatkovni portal), Http://www.stat.si/pxweb/ Database /Ekonomsko/14_poslovni_sub jekti/ 03_1 4 184_demogr_podj/01_14510_novonastala/01_14510_novonastala .asp, (12. 6. 2008).

SORS, (2009), Poslovni subjekti, število podjetij, (SI-Stat podatkovni portal), Http:// www. stat.si/pxweb/Database/Ekonomsko/14_poslovni_subjekti /01_14188_podjetja/ 01 _ 4 188 _podjetja.asp, (14. 2. 2009).

Storey, D. J., (1994), Understanding the small business sector, (London: Routledge).

Sufian, F., (2010), "Assessing the impact of financial sector restructuring on bank performance in a small developing economy", Ekonomska istraživanja, 23 (2): 11-34.

Vernon, R., (1966), "International investment and international trade in the product cycle", Quarterly Journal of Economics, 80 (2): 190-207.

\section{DINAMIKA PODUZEĆA DRVNE INDUSTRIJE U SLOVENIJI}

\section{SA ŽETAK}

Ovaj rad istražuje utjecaj dinamike velikih poduzeća drvne industrije na dinamiku mikro i malih poduzeća koji rade u toj djelatnosti koristeći podatke anketnog upitnika i statističke serije podataka. Osim toga ulazak $i$ izlazak mikro i malih poduzeća drvne industrije objašnjavan je sa faktorima potražnje, dodane vrijednosti $i$ profitabilnosti kapitala. Empirijski rezultati pokazuju relativno skroman učinak dinamike velikih poduzeća na dinamiku mikro i malih poduzeća u drvnoj industriji. Stopa dodane vrijednosti po zaposleniku i stopa profitabilnosti kapitala značajno su povezane s novim ulaganjima, osobitu u novu tehnološku opremu. Lakši pristup financijskim sredstvima za mikro i mala poduzeća po prihvatljivim jamstvima i smanjenje troškova financiranja kapitala su među mogućim mjerama za poboljšanje razvoja poduzetništva u drvnoj industriji i lakši prodor mikro i malih poduzeća na strana tržišta. Pored toga bi trebalo smanjiti izvoz sirovina i poluproizvoda, te povećati izvoz proizvoda i usluga sa većom dodanom vrijednosti.

JEL klasifikacija: D22, L25, L69, C12, C81;

Ključne riječi: Dinamika poduzeća, konkurencija, drvna industrija, Slovenija 